\title{
Prerequisites for Sustainable Government Borrowing Within Currency Board System*
}

\author{
Aura Draksaite, Vytautas Snieska, Gitana Valodkiene
}

Kaunas University of Technology

K. Donelaicio st. 73, LT-44029, Kaunas, Lithuania

E-mail.aura.draksaite@ktu.lt,vytautas.snieska@ktu.lt,gitana.valodkiene@gmail.com

cross $^{\text {ref }}$ http://dx.doi.org/10.5755/j01.ee.27.2.13753

Financial stability of an economy is one of the most important priorities in many countries around the world. Although in many cases financial resources are preferably generated within a given economy, often there is a necessity to borrow the funds abroad.

In order to maintain the sustainability of the economy, the borrowing abroad also should comply with the certain respective regulations. Specific regulations depend on the peculiarities of the economy itself. There is a complex set of the factors to be considered when analyzing the sustainability of the economy. In this article, the importance of the monetary system arrangement is emphasized, namely the case of currency board system is analyzed. The aim of the paper is to reveal the prerequisites for sustainable government borrowing within currency board system.

The main research methods used are systematization and generalization of the scientific literature, quantitative and qualitative analysis of the primary and secondary data, graphic presentation of the data and results. Also the case of Lithuania's government borrowing is presented. For the evaluation of risk, @ Risk package has been used. Conclusions of the paper provide the review of both general and the specific prerequisites for sustainable government borrowing within currency board system. The case study showed that given current government debt management policy and based on an assumption that in similar circumstances economy can perform similarly, it can be stated that in the long run Lithuania's borrowing can be considered as having the attributes of sustainability.

Keywords: Government Borrowing, Sustainable Borrowing, Currency Board System, Government Borrowing Prerequisites, Government Debt Management.

*This research was funded by a grant (No. IEP-01/2012) from the Research Council of Lithuania

\section{Introduction - the Problem Genesis}

It is widely acknowledged that if managed properly, government's debt should not be a burden on the economy. The need for government's borrowing, management of the debt, including management of the debt-associated risk are analyzed by Drudi and Giordano (2000), Tomz and Wright (2007), Genberg and Sulstarova (2008), Vlasenko et al. (2009), Fuentes and Saravia (2010), Bordo et al. (2010), Baldacci et al. (2011), Snieska and Draksaite (2010), Korinek (2011), Agliardi et al. (2012), Knedlik and Von Schweinitz (2012), Gatzert and Martin (2012), Melecky (2012), Duan and Van Laere (2012) and many more.

The causal nexus between the government's borrowing and sustainability of the economy is analyzed from different perspectives in the works by Douglas et al. (1998), Von Wijnbergen and France (2012), Aspromourgos et al. (2010), Cebula (2002), Moinescu (2013), Faraglia et al. (2013), Molanescu and Aceleanu (2011), Legrenzi and Milas (2012), Liliko et al. (2009), Taylor et al. (2012), Eggertsson and Krugman (2012), Snieska and Draksaite (2011), Neck and Sturm (2009), Burnside (2004) and others.

The existing research provides quite different concepts of the sustainability of the economy, and for that matter, of the sustainability of the government's borrowing. Different prerequisites for the government borrowing have been discussed in the scientific research in different perspectives.
Also, the impact of the monetary arrangement on the various aspects of the economy is analysed (Togay \& Kose, 2013; Katsimi, 2007; Gurtner, 2003; Tsang \& Ma, 2002). In this article, the relation between the monetary policy arrangement and the prerequisites for the sustainability of the government borrowing is analysed. Monetary policy arrangement is important for the economy because it determines the impact of the monetary policy decisions on the economy (Dafflon, 2002; Afonso, 2005; De Grauwe \& Ji, 2012; Campa, 2012) and the possibilities to apply specific tools for the debt management. In case of the currency board system, options to apply different debt management tools are quite limited. Given all the research above and the different angles of their research objects, the resumptive analysis of the prerequisites for sustainable government borrowing within the currency board system has not been done.

Therefore, the aim of this paper is to reveal the set of prerequisites for sustainable government borrowing within the currency board system.

For the analysis of the currency board system concept in terms of the object of the research, systematization and generalization of the scientific literature was done. Generalization of the findings was used to identify the peculiarities of the sustainable borrowing in the economy within the currency board system, as well as to define the respective concept, used in this research. Qualitative 
analysis of the respective primary and secondary data has been performed.

Systematic approach is applied throughout the research

Also case study method is applied to illustrate the compliance of the government strategy with the necessary prerequisites for sustainable government borrowing in economy within currency board system. Lithuania's case is analyzed, more specifically - the analysis of borrowing of Lithuania's central government is performed. Time period of the years 2004-2014 was selected. This specific period of time was selected because before the year 2004 Lithuania had significantly different strategy of government borrowing to compare it with the strategy after 2004 (which is because in the year 2004 Lithuania has joined the European Union). Case study employs analysis of the secondary and primary data, quantitative and qualitative analysis of which is performed. For the evaluation of risk, @Risk package was used. Graphic presentation is used for the illustration of the argued statements and findings of the research.

\section{Conception of the Sustainable Government Borrowing: the Economy Solvency Approach}

There are many variations of the conception of sustainable government borrowing. The approach to this subject depends on the different aspects and intends of researchers.

Furthermore, the term "government" can be misleading as it is used in different meanings. In this article, we use the term to describe the central government, as it is described by Eurostat - the statistical office of the European Union. According to Eurostat, general government comprises the following subsectors: state government (where applicable), central government, local government, social security funds (http://epp.eurostat. ec.europa.eu/statistics_explained/index.php/Structure_of_g overnment_debt\#General_government) (Draksaite, 2014).

There is less ambiguity concerning the term "borrowing". In case of government borrowing, in general, it is associated with the outstanding debt. In many cases, the government's debt also can be described as one incurred by country's highest executive authority or a central government, which is authorized to perform on behalf of the state (Draksaite, 2014). As suggested by the International monetary fund, debt can be described as all liabilities, originated from the debt based financial claims (Public sector debt statistics, 2011).

Despite the many different approaches to the conception of the sustainability of the government debt, one of the most common notions of the sustainability of the debt is based on the solvency of the debtor. This approach is adopted in this article as well. To be more specific, in this research we adopt the concept based on the assumption, that to reasonable degree, sustainability of the government debt can be defined as the solvency of the government in terms of debt financing. The solvency, of course, should be considered in the long term and taking the stochastic nature of the economy into the consideration.

On the other hand, the problem arises from the definition of the solvency itself. More specifically, problematic is the evaluation of the solvency of the debtor over the long period of time, i.e. measurement and evaluation of the long term solvency of the debtor.

The conception of solvency of government can be explained by several different viewpoints. While there are quite a lot of theories, explaining the government solvency, five of them can be distinguished: future generations' approach, Keynesian approach, overlapping generations' model, classical approach and neoclassical approach (Vaughn \& Wagner, 1992; Clingermayer, 1991; Barro, 1990).

According to new generations' approach, debt incurred by the present generations cause accumulation and increase of the debt of the future generations. Also, the benefit of the government borrowing is taken into the account. Therefore, it is argued that is present debt is necessary for the benefit of the future generations, the borrowing can be justified and future generations' payment for the present debt is acceptable.

In case of the Keynesian approach, the difference between the foreign and domestic borrowing is pointed out. It is argued that domestic debt is not causing the increase of the debt burden, because future generations get indebted to themselves, i.e. domestic debt is paid to the domestic creditors and it is paid from the income of the state/economy, therefore consumption does not get affected. But the situation is different in case of the foreign debt. In case of borrowing abroad, indebtedness increases and the consumption decreases because of the debt financing and interest payment. Also, the benefit of the borrowed funds is considered, i.e. if the benefit exceeds the cost of borrowing, the borrowing can be justified and if cost is higher - the future economic welfare is thought to be decreasing.

According to the overlapping generations' approach, at every given time there are several different generations living in the same economy. Thus it is argued that borrowed funds are used for the benefit of all the citizens, and debt burden increases for all the generations in the tax form because of the increased indebtedness of the government.

In the classical approach, it is argued that if government borrowing is not effective, it has negative effect on the domestic investment, income and economic welfare in the future. One of the assumptions in the neoclassical approach is that government borrowing is ineffective, which in turn determines the relation between the different generations and the future indebtedness.

Of course, all of the above mentioned approaches have specific preconditions, upon which they are based. Neither the preconditions, nor the validity of the presented approaches are the subject of this research.

In terms of sustainability of the government debt and sustainable borrowing, in this article we adopt the approach, according to which it can somewhat be said, that the government's borrowing policy is not sustainable, if, over time, the debt of the government has significantly increased - or an increase is likely to occur in the nearest future - and the government is no longer able to meet its debt obligations in terms of financing it in the long run (Draksaite, 2014). 
In the research, the sustainable government debt, in terms of sustainable borrowing, is understood as such level of the government debt, resulted from the governmental debt management, which ensures meeting the government borrowing demands and which does not negatively affect long term creditability or the solvency of the government and the ability to meet the long-term debt obligations (Draksaite, 2014). In this case, the strategy of the sustainable borrowing should be focused on such selection of borrowing and debt management means, which would contribute to the long term solvency of the government, ensuring the fulfilment of the borrowing needs simultaneously. In consideration of such means, debtassociated risks (e.g. risk of change of exchange rates, refinancing risk, economic vulnerability attributed risk etc.) must be considered, as well as the borrowing costs to the government. The two must be compared and evaluated at all times. Also, as already mentioned, in evaluating the sustainability of the government's borrowing strategy and in formulating the according strategy, it is imperative to consider the long time period. These factors would contribute to the long term increase of the government's ability to meet the demands of its creditors.

\section{The Concept and Peculiarities of a Currency Board System in Terms of Government Borrowing}

The monetary policy arrangement is essential in making decisions regarding the sustainability of the debt and debt management in general. More specifically, the monetary arrangement determines the limits within which the debt management means can be applied and the ability to apply specific means or methods.

While there are a lot of different aspects of the monetary policy that affect the strategy of sustainable government borrowing, one of the most important ones is the exchange rate system/regime and its arrangement in the economy.

As well known, there are various exchange rate regimes, extreme regimes being the fixed rate and the floating rate. The currency board system falls under the fixed regimes group. In case of the currency board system, the link between two currencies is fixed rigidly. This, in turn, brings not only advantages (the prime reason for implementing the currency board system), but also disadvantages to the economy. Especially considering the ability to adjust debt levels in case if such need is in order to be made.

Under the currency board system, the fixed exchange rate between the domestic currency and the peg currency is guaranteed by the monetary authority. Therefore stability of the domestic currency gets increased and the control of the money supply is more strict, which may add to the increase of the credibility of the economy. Also, discouragement of the speculative attacks is considered to be one of the currency board system advantages (Katsimi, 2007). On the other hand, there are evidences that currency board systems are not immune to suchlike attacks (Tsang \& Ma, 2002).

Also, moderation of currency board systems could be applied. For example, in case of European Union, there is an exchange rate mechanism (ERM II) implemented.
There are studies, arguing that allowing exchange rate to fluctuate within ERM II limits would be more beneficial for the economies of the countries that are seeking for the membership in the euro zone than implementation of the currency board system within the ERM II (Katsimi, 2007). Katsimi (2007) argues that this would reduce the market uncertainty. But this argument is coupled with the statement that the discussed change would be beneficial if the country in question would significantly improve economically. This is most basic common sense and the stochastic nature of the economy with its relative consequences is ignored.

As for the management of the inflation, it is argued that currency board should cause the convergence of inflations expectations between the domestic economy and the anchor economy, taking into account the time lag and the remaining residual inflation (Gurtner, 2003). Ghosh et al. (2000) state that many modern currency board systems significantly increased the credibility of economies following the period of high inflation or hyperinflation. Also these authors state that "countries with currency boards experienced lower inflation and higher (if more volatile) GDP growth compared to both floating regimes and simple pegs. The inflation difference reflects both a lower growth rate of money supply (a "discipline effect"), and a faster growth of money demand (a "credibility effect")." Nevertheless, the research adds that even though the increase of the GDP is significant, it may be based merely on the "rebound from depressed levels" (Ghosh et al., 2000).

Nevertheless, even with the adopted currency board system, there are no guarantees for the all expected advantages if there is no adequate, sustainability oriented economic-financial policy imposed in the economy.

Furthermore, the two groups of the economy affecting factors must be considered: endogenous and exogenous. Whereas endogenous factors can be controlled, the exogenous factors, such as global financial crisis, economic shocks, significant changes in the anchor economy etc., cannot be influenced in any way.

One of the principal factors to be considered is the capital flows, their origin, their volatility and sensitivity to the changes of the market or economic circumstances in general. This must be taken into account when considering the government borrowing strategy.

Also, in case of the currency board system, it is important to establish the type of risk that may be incurred - whether it is systemic or efficiency risk (Tsang \& Ma, 2002). This is important in order to make the necessary adjustments of the government borrowing strategy.

Also, in order to maintain the sustainable economy and simultaneously - the fixed currency rate, relative flexibility of economic-financial policy of the economy and relatively quick implementation of the changed policy must be ensured.

There are examples, when countries, adopting currency board system, were not able to take advantage of it because of the not efficient domestic economic-financial policy and unfavorable changes of the external economy. Therefore, all the possible specific circumstances of every different economy must be taken into account when analyzing its tradeoffs of implementation of the currency 
board system. The same is applicable in case of borrowing within the currency board system.

In terms of strategy for the sustainable borrowing of the government, implementation of the currency board system also adds a restriction in terms of the variety of the means/tools to maintain the government borrowing sustainable.

On the other hand, the currency board system does not limit the government debt management and government borrowing choices with the exception of the ones that are based on the change of the value of the currency.

In principle, economies with the currency board system cannot change the exchange rate of the currency, i.e. depreciate or appreciate/revaluate the currency and thus "artificially" affect the debt level.

Thus the increasing level of the debt in economy within currency board system is very sensitive to the sustainability of the borrowing, which relies on the other means (i.e. not involving regulation of the value of the currency) of sustainability maintenance. In this respect, except for the latter limitation, the sustainability of the government borrowing (which in this research is evaluated by the solvency of the debtor) depends on the factors, influencing the government borrowing and debt management, taking the specifics of the economy into the consideration and not limiting it otherwise.

\section{Solvency Oriented Government Borrowing Within Currency Board System}

In addition to the stated argument, it is very important to consider the openness and size of the economy in question. It is obvious that open small economies within currency board system are significantly sensitive to the change of economic environment and the borrowing cost. Though big open economies within currency board system are not immune to the changes of external economic environment, they have much more effective coping mechanisms (Pisani, 2011; Jeanne \& Ranciere, 2011; Cuadra \& Sapriza, 2008; Fisher, 2008).

Therefore, in terms of economic policy making, we argue that one of the most important prerequisites for sustainable government borrowing in a small open economy is the government's stance on the need of the economic-financial sustainability itself, i.e. it is supposed to be pro sustainability.

Sustainable government borrowing directly influences the solvency of economy, also increases the financial stability. Furthermore, sustainable government borrowing often causes decrease in the national budget deficit or can be a reason of increase of the budget surplus. In case of sustainable government debt, the credit ratings are relatively good, which normally allows borrowing at lower cost. Following the non-sustainable government borrowing patterns may cause unmanageable increase of the debt, inability to meet the debt liabilities, increase of the borrowing cost and refinance costs, followed by increase of national budget deficit, possible decrease in investments, country's economic recession (especially in the small open economy countries) and can cause the economic crisis. Also, in case if considerably big part of the debt is debt to foreign creditors, theoretically there is even a possibility of foreign creditors gaining the political influence on the country. On the other hand, small open economy has very limited or even no choice of creditors and cannot influence the cost or other lending conditions.

Also as the management policy of a government debt is an inseparable part of the country's general economic policy, in modern open economy countries, government's borrowing is an inevitable and important factor of the economic development. Not only the economic efficiency, but also the well-being of the society depends on the possibilities of a government to borrow. So, a government of the open economy has to evaluate their future borrowing potential responsibly. It is even more relevant to the small open economy countries, whose economy is much more sensitive to the changes in the international market. In order to achieve a sustainable economic development of the country, solvency based sustainability should be regarded as one of the strategic goals of the country.

Furthermore, considering the size of economy, nonsustainable management of the government's debt can cause the lowering of credit ratings, as well as reduction of the borrowing possibilities, an economic decline, stagnation or even bankruptcy of the country (Neck \& Sturm, 2009; Afonso \& Rault, 2010; De Grauwe \& Ji, 2012; Snieska \& Draksaite, 2013). If there is no sustainable debt management, in case of economic shock any country could suffer these consequences. Small open economy would be affected to a greater extent to compare to a big open economy and would be more volatile to such sudden unexpected changes of economy. Non-sustainable government borrowing in big open economy's case could cause even more significant negative effect on the global markets.

Also, in case of both small and big open economies, important is the competency of debt strategy developers and the ones, who implement it, as it is important to take into the consideration all the risk, associated with borrowing. Specially, keeping in mind the stochastic nature of economy. The best sustainability based government borrowing strategy could be ruined by the incompetence of the respective decision makers. The same can be true in case of the chase after the populistic ideas instead of securing sustainability of the present or imminent debt. Cases like this can be often observed in current economy policy making all over the world.

The other threat to the solvency in case of borrowing by economy within currency board system is the ability to repay the debt, which generally depends on the economies potential to raise the necessary funds (Pattillo, et al., 2004; Durbarry, Seetanah, \& Padachi, 2008). For example, higher production growth rate is likely to improve the prospects of intertemporal solvency.

Also there are general preconditions for the sound management of the debt, in spite of the different evaluation and concepts of sustainability and the sustainable debt. Such is willingness to secure the conditions that would be necessary in case of implementation of significant structural reforms of the economy (Thornton, 2012; Baldacci et al., 2012). Although, structural reforms are quite an extremity, the success of their implementation greatly depends on the ability to adopt the changes and consequently develop the new system. 
Other general prerequisite is the ability to use the borrowed funds effectively (e.g. renewable capital (Hartwick, 2011), ,productive“ investment (Pattillo, et al., 2004) etc.). This is also quite a common sense in any case of management of borrowed funds. Nevertheless, it is much more significant for the economies within currency board system as they are restricted from the adjustment of debt level adjusting the exchange rate or employing the before mentioned methods, used by countries whose currency is not pegged to any other currency.

Also in case of limited artificial solvency adjustment means, and in order to ensure the solvency in terms of returning the borrowed funds, there should be a proper debt monitoring system set. One of the functions of such system could be monitoring and constant comparison of borrowing costs with the benefits, gained by borrowing.

One of the more general prerequisites, when considering government borrowing in country within a currency board system, is the relative importance of the base currency in the global market. The other prerequisite that also should be considered is the level of difficulty to withdraw from the currency board system. Therefore for countries, considering the pegging of their currency, it is important to evaluate the base currency with caution.

Next, the case of Lithuania is analyzed, evaluating its solvency in regard to government borrowing. Data from official statistics bulletins and databases have been used (Lithuania's government's and state control bulletins, EU official bulletins, Eurostat, Lithuania's national statistics database, EU and Lithuania's respective regulations regarding the borrowing, International Monetary Fund database - due to limit to the size of the paper and the commonness of the sources, bibliographic reference of these information sources is not provided). The following are some of the main findings of the case study.

Credit default swap (CDS) premium $(S)$ estimated according to default probability $(p)$ and solvency reestablishment coefficient $(R)$

(http://www.centralbanking.com/tag/credit-defaultswaps):

$$
\mathrm{S}=(1-\mathrm{R}) * \mathrm{p}
$$

Deficit dynamics has been established by evaluating the average rates $\left(R_{c d}\right)$ of prime deficit change $\left(D_{c}\right)$ and prime surplus $(p)$ :

$$
\begin{aligned}
& \mathrm{R}_{\mathrm{cd}}=\left(\sum_{n}^{m} \frac{D_{c(m)}-D_{c(m-n)}}{D_{c(m-n)}} \cdot 100\right) / \mathrm{m} ; \\
& \text { where } D_{t}=\frac{1+r_{t}}{1+g_{t}} * D_{t-1}-p_{t}
\end{aligned}
$$

Prime budget deficit $(P D)$ evaluated taking into account the budget $(B)$ of the last period, nominal interest rate $(i)$, inflation rate $(\pi)$, GDP change rate $(g)$ and nominal GDP $(P Y)$ (with reference to Legrenzi \& Milas, 2012; Sopek, 2009; Izak, 2009; Cebula, 2002; Uctum \& Wickens, 2000; etc.):

$$
\mathrm{PD}_{\mathrm{t}}=-\frac{B_{t-1} \cdot\left(i_{t}-\left(\pi_{t}+g_{Y}\right)\right) \cdot P_{t} Y_{t}}{P_{t-1} Y_{t-1}} ;
$$

Analysis of the Lithuania's prime budget deficit according to formula 3 (where all the respective variables where analyzed), it was established that unfavorable conditions for the maintenance of the sustainable level of the debt level (as the indicator shows limit which is optimal for the stability of debt to GDP ratio) was only during period of the year 2009-2010.

Calculation of forward rates, interest swap results and simulation using @Risk package has been used for the risk analysis. Example of specific condition simulation is shown in the Figure 1, metadata and result can be seen in the figure.

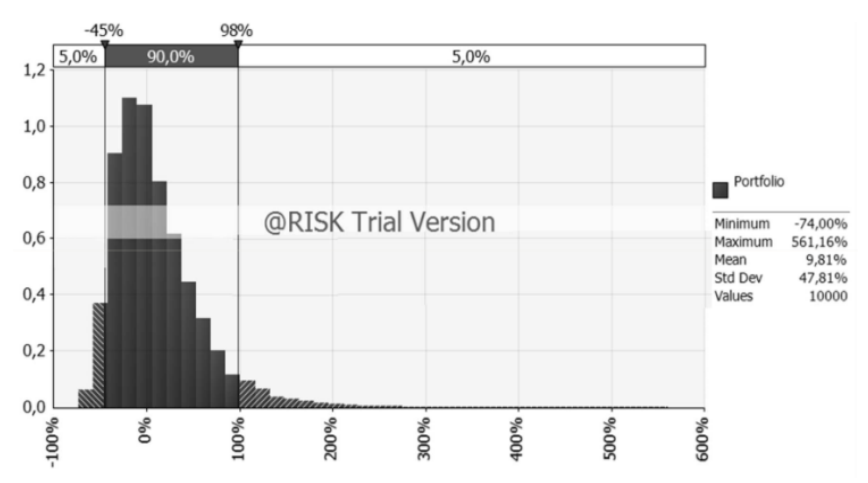

Figure 1. Result of simulation with 1000 iterations

The currency board was established in Lithuania since the year 1994. Mainly it was done in order to increase the creditability and stability of the economy, the stability of the currency, and to better manage the inflation.

The former currency of Lithuania - Litas - was pegged to the USA dollar from the year 1994 to year 2002 at the rate of 4 to 1 . From year 2002 to the end of the year 2014 Litas was pegged to the Euro at the rate of 3,4528 to 1 (within the exchange rate mechanism ERM II since year 2004). The decision to choose Euro for the peg currency was based on the intent of Lithuania to join the euro zone. From the $1^{\text {st }}$ of January 2015, Litas is replaced by Euro, which is now the official currency of Lithuania.

Although general debt level of Lithuania was never high if to compare to EU average, being small open economy, Lithuania faced challenge to maintain the sustainability of the borrowing and the solvency of the country.

There is no use to analyze sustainability of the debt in Lithuania during the period before joining the European Union, because after becoming the member of the Union, the regulation of the borrowing, as well as the goals, conditions and debt evaluation methods have changed significantly. In year 2004, the debt structure of the government sector was adjusted.

All the laws and acts, related to the government's borrowing policy are passed by the Seimas of the Republic of Lithuania, which, each year, also ratifies the borrowing limits. The limit of the government's borrowing and the limit for the interest cost is also established in the guidelines of the government's borrowing and debt management.

In Lithuania, according to the government's debt regulating laws, when taking a loan, borrowing and managing the debt, the Ministry of Finances has to make sure that borrowing was carried out at minimal costs and with acceptable risk level in medium term (in a period up to five calendar years). 
In order to manage the risk of liquidity and change of interest rate, a short-term debt limit is established in the government's medium-term borrowing strategy; also limit is set for the size of debt with floating interest rate.

Following the Lithuanian law, the description of borrowing and debt management guidelines for the year 2011-2014 (which has substituted the goals, tasks and means provided in the middle-term borrowing and debt management strategies of 2008 and 2009), the government was obliged to undertake new debt obligations solely in litas and/or euro.

At the end of the budget year, besides the annual budget report and other financial reports, government also provides Seimas with the reports of government debt and warranty obligations. These reports are evaluated by the State control, which prepares respective conclusions, which are submitted to Seimas.

Thus in Lithuania, and now even considering the fact that Lithuania is one of the Eurozone countries, government borrowing and debt management are all regulated by the law.

The comprehensive analysis of Lithuania's government borrowing (for the period of year 2004-2014) in terms of borrowing sustainability and solvency of the country has been performed, the main results of which are presented next.

After evaluation of the resent financial crisis impact on the sustainability of government debt, it was established, that a sudden increase of the debt in year 2009 was mainly caused by the fact that during the period of the financial crisis, the borrowing was more expensive, the borrowing costs were higher, and the credit rating was lower (Draksaite, 2014). Both the variation of the ratio of central government debt to GDP and the variation of the ratio of government's net borrowing to GDP over the time are shown in Figure 2 (a).

a)

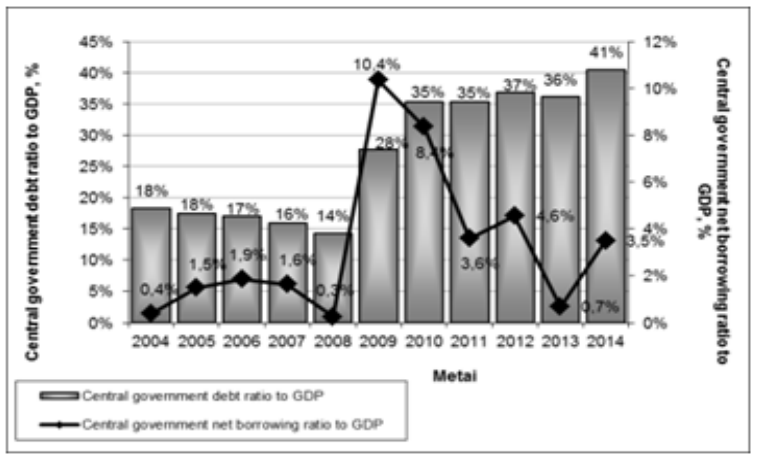

b)

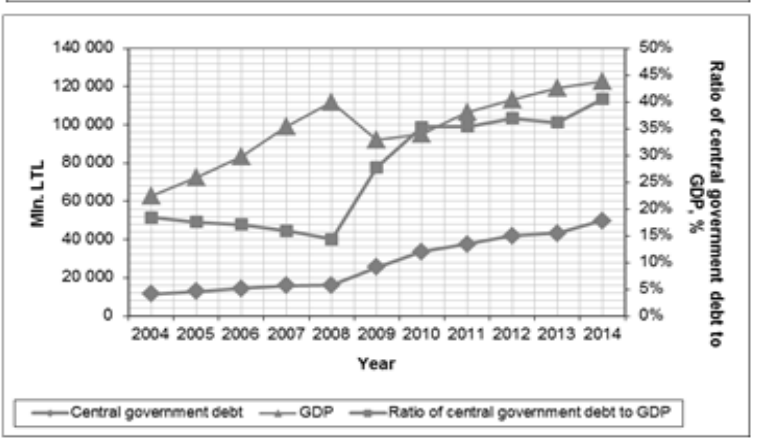

Figure 2. Central government debt ratio to GDP, central government debt, GDP, net borrowing ratio to GDP, 2004-2014 year period
During the period since the global financial crisis to year 2012, the average rates of the Lithuanian central government's debt increase were 2,53 times higher than the average rates of the GDP increase.

Also it was established that there is no risk of changes in exchange rate. The risk of change of interest rates and the risk of liquidity (refinancing) are considered to be the biggest threat (in relevance to manageable risks) (Draksaite, 2014).

Assessing the sustainability of the government debt as an ability to meet the financial obligations (the conception provided by the Commission of the European Communities), and given the ratio of the government debt to GDP, and having assumed that the increase of the ratio of the debt to GDP will not change, the government debt can be considered sustainable (Snieska \& Draksaite, 2013).

However, since year 2009, the rates of the GDP increase are lower than the rates of the government debt increase (Figure 2(b)). So, evaluation of sustainability tendencies of the debt in respect of interdependency between the two rates, government debt in Lithuania will be sustainable in case if GDP increase rates will be higher, as it was before the later global finance crisis.

During period of year 2004-2014, the rates of government debt increase were higher than the rates of the debt management costs (Draksaite, 2014). In this regard, for the debt to be considered as sustainable, the level of cost of debt servicing should not alter significantly or should improve.

During the periods from 2004 to 2008, and from 2009 to 2013 , the primary deficit of the central government decreased. The net borrowing of the central government has decreased during the periods from year 2004 to 2007, and from year 2009 to 2013. At the same time, the increase of GDP, the debt of central government, the cost of interest rates (decreased in year 2004-2007), the ratio of the central government debt to GDP ratio has also increased (decreased in year 2004-2008) (Snieska \& Draksaite, 2014). Since year 2012, the declared top priority of the government's borrowings is refinancing of the debt and the need to reduce the budget deficit.

Taking into account these tendencies, and assuming that the central government debt obligations are met on time, the assumption that from the year 2004 to 2014 the biggest threat to sustainability of the central debt was by the increase of the debt cost can be made. What is even more important, based on the results above, it can be assumed that the increase of the debt cost was caused by the global finance crises, and not by the debt management decisions (given the long term debt management strategy) The dynamics of the analyzed indicators is shown Figure 3 (a). 


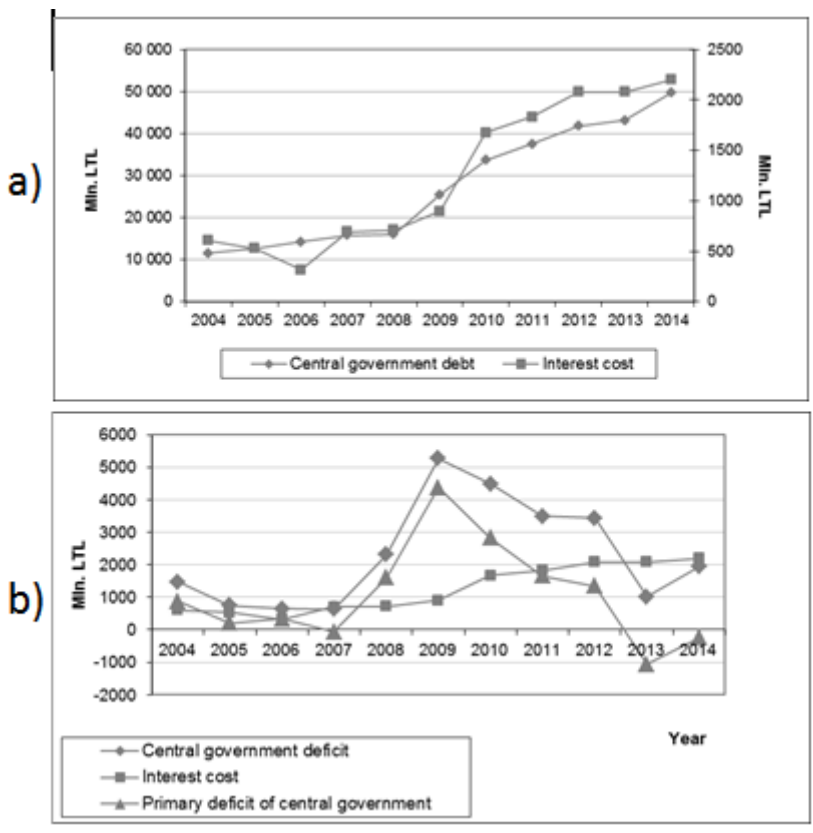

Figure 3. Central government debt, interest cost, 2004-2014 (a); central government debt, interest cost, primary deficit of the central government (b), 2004-2014

Also, after primary investigation of the data, the assumption that credit interest risk is one of the main factors, contributing to the volatility of the budget respective data presented in Figure 3(b)) has been made.

The relation has been calculated between Lithuania's and Germany's CDS, as well as between Lithuania's central government debt ratio to GDP and credit interest. In both cases strong correlation and statistical significance of the correlation has been established (Draksaite, 2014).

The other conclusion form the Lithuania's case study is that the risk of interest rate changes is not a major contributor to volatility of Lithuania's government debt level. This is because critical level of the debt means were issued with the fixed interest rates.

Also, analysis showed that the risk of refinancing in Lithuania is reduced by coordinating (in advance) the dates of payment to creditors and government's borrowing in the market. Also, aggregation of financial resources is planned in advance. The combination of these measures was often used.

Further, it was established that if the operational risk is reduced or eliminated, and the other factors are stable, the credit and refinancing risks could be also reduced. Considering the solvency of the country, it was established that as one of the main causes of the government debt increase, the increase of interest cost, risk of refinancing should be managed with the high precaution.

The risk of interest rate change, as well as risks of other kinds, can be fully eliminated by hedging. The Lithuanian government debt is currently hedged against the risks of interest rate change only relatively.

The cost of not hedging can be measured by the extent of incurred losses if the risk was to occur. However, hedging against risk of interest rate change is expensive. Therefore, this strategy should be compared to the alternative strategies.
The possibility to increase borrowing with floating rates should be considered in regard of the cost of financial derivative means, as discussed in the dissertation.

On condition that the forecast of the increase of pension fund needs is valid, and considering the fact that Lithuania cannot significantly influence the international market and is totally dependent on it, the long-term hedge benefits are likely to exceed the hedging costs.

\section{Conclusions}

Although currency board system adds specific limitations to the management of solvency of the country through the adjustment of the debt level, it prompts maintenance of debt sustainability due to rational borrowing. On the other hand, the currency board system does not limit the government debt management and government borrowing choices with the exception of the ones that are based on the change of the value of the currency. Nevertheless, currency board system decreases the exchange market volatility only to a degree.

In context of the research, one of the most significant peculiarities of an economy within currency board system is its inability to adjust the government debt level by alternating monetary policy, e.g. by changing the currency exchange rate. Economies within the currency board system cannot change the exchange rate of the currency, i.e. depreciate or appreciate/revaluate the currency and thus "artificially" affect the debt extent. Thus the increasing extent of the debt in economy with currency board system is sensitive to the sustainability of the borrowing.

In spite that many modern currency board systems have significantly increased the credibility of economies following the period of high inflation or hyperinflation, it should be considered with caution because of the natural rebound from the downturn of the economy. Furthermore, even with modified currency board system, there are no guarantees for the all expected advantages if there is no adequate, sustainability oriented economic-financial policy imposed in the economy.

In addition to the preferable policy, when evaluating the government debt sustainability in economy within currency board system, specifications of the size and openness of the economy must be considered as they define the possibilities not only to cope with the debt levels, but the ability to influence the borrowing conditions. For instance, in terms of economic policy making, considering government's readiness and willingness to implement structural reforms in the country, the scope of currency related reforms would be limited because of the specifics of the currency board system. Also relative flexibility of economic-financial policy of the economy and relatively quick implementation of the changed policy must be ensured.

Other important prerequisite for the sustainable borrowing within the currency board system is establishment of type of risk that may be incurred whether it is systemic or efficiency risk.

Furthermore, in the article we argue, that other significant prerequisites for the sustainable government borrowing in economy within currency board system are: government's policy, oriented towards a sustainable 
Aura Draksaite, Vytautas Snieska, Gitana Valodkiene. Prerequisites for Sustainable Government Borrowing Within ...

development of the economy; the competency of debt administrators and the developers of the government's borrowing strategy; the ability to generate funds to redeem debt; continuous monitoring of sustainability of the government debt; inclination and ability to implement structural reforms if necessary; an efficient usage of the borrowed funds.

Sustainable borrowing is likely to cause an increase of solvency of debtor. Given a sustainable debt of the government, the creditworthiness of a country is relatively high, which allows borrowing at relatively low cost. Nonsustainable government borrowing patterns may cause unmanageable increase of the debt, inability to meet the debt liabilities, increase of the borrowing cost and refinance costs, followed by increase of national budget deficit, possible decrease in investments, country's economic recession (especially in the small open economy countries) and can cause the economic crisis. In case of economies with currency board system, these consequences can be even worse, because of limited means of prompt adjustment of the debt (and risk) level.
Economies within currency board system are restricted from adjustment of debt level by alternating monetary policy. Therefore, such economies could take into the consideration revision or possibility of alteration of the current system or even comparative evaluation of the change of the existing system. For the substantiation of the pros and cons of such changes much more extensive analysis is required to be done.

The case study showed that given current government debt management policy and based on an assumption that in similar circumstances economy can perform similarly, it can be stated that in the long run Lithuania's borrowing can be considered as having the attributes of sustainability.

As the research results are reliable under the specific constraint, further research can involve specific limitations by the currency board system and the impact of the specific factors on the government borrowing. Also the impact of both the inflation policy and debt management quality on the sustainability of the government debt can be further analyzed.

\section{Acknowledgments}

This research was funded by a grant (No. IEP-01/2012) from the Research Council of Lithuania.

\section{References}

Afonso, A. (2005). Fiscal sustainability: The unpleasant European case. Finanzarchiv, 61(1), 19-44. http://dx.doi.org/10.1628/0015221053722532

Afonso, A., \& Rault, Ch. (2010). What do we really know about fiscal sustainability in the EU? A panel data diagnostic. Review of World Economics, 145(4), p. 731-755. http://dx.doi.org/10.1007/s10290-009-0034-1

Agliardi, E., Agliardi, R, Pinar, M., Stengos, Th., \& Topaloglou, N. (2012). A new country risk index for emerging markets: A stochastic dominance approach. Journal of Empirical Finance, 19(5), 741-761. http://dx.doi.org/10. 1016/j.jempfin.2012.08.003

Aspromourgos, T., Rees, D, \& White, G. (2010). Public debt sustainability and alternative theories of interest. Cambridge Journal of Economics, 34(3), 433-447. http://dx.doi.org/10.1093/cje/bep010

Baldacci, E., Gupta, S., \& Mati, A. (2011). Political and Fiscal Risk determinants of Sovereign Spread in Emerging Markets. Review of Development Economics, 15(2), 251-263. http://dx.doi.org/10.1111/j.1467-9361.2011.00606.x

Baldacci, E., Gupta, S., \& Mulas-Granados, C. (2012). Reassessing the fiscal mix for successful debt reduction. Economic Policy, 71, p. 365-406. http://dx.doi.org/10.1111/j.1468-0327.2012.00287.x

Barro, R. J. (1990). Government spending in a simple model of endogenous growth. Journal of political Economy, 98(5), p. 103-125. http://dx.doi.org/10.1086/261726

Bordo, M. D., Meissner, Ch. M., \& Stuckler, D. (2010). Foreign currency debt, financial crises and economic growth: A long-run view. Journal of international Money and Finance, 29(4), 642-665. http://dx.doi.org/10.1016/ j.jimonfin.2010.01.002

Burnside, C. (2004). Fiscal Shocks and Their Consequences. Journal of Economic Theory, 115, 89-117. http://dx.doi.org/ $10.1016 / \mathrm{S} 0022-0531(03) 00252-7$

Campa, J. M. (2012). Fiscal Challenges in the Euro Zone. Asian Economic Policy Review, 7, 180-197. http://dx.doi.org/ $10.1111 / \mathrm{j} .1748-3131.2012 .01231 . x$

Cebula, R. J. (2002). A contemporary investigation of causality between the primary government budget deficit and the ex ante real long term interest rate in the US. PSL Quarterly Review, 55(223), 417-435.

Clingermayer, J. C. (1991). An intergenerational transfer model of state debt financing. Public Choice, 72(1), 13-21.

Cuadra, G., \& Sapriza, H. (2008). Sovereign default, interest rates and political uncertainty in emerging markets. Journal of International Economics, 76(1), 78-88. http://dx.doi.org/10.1016/j.jinteco.2008.05.001

De Grauwe, P., \& Ji, Y. (2012). Mispricing of Sovereign Risk and Macroeconomic Stability in the Eurozone. JSMSJournal of Common Market Studies, 50(6), 866-880. http://dx.doi.org/10.1111/j.1468-5965.2012.02287.x

Dafflon, B. (2002). Local public finance in Europe: balancing the budget and controlling debt. Cheltenham Northampton: E. Elgar. 302. ISBN 1-84064-878-3 
Draksaite, A. (2014). Government debt stabilization in a small open economy within currency board system. Procedia social and behavioral sciences: 19th international scientific conference Economics and Management 2014, ICEM2014, 23-25 April 2014, Riga, Latvia. 2014, vol. 156. ISSN 1877-0428 p. 524-528.

Drudi, F., \& Giordano, R. (2000). Default risk and optimal debt management. Journal of Banking \& Finance, 24(6), 861-891. http://dx.doi.org/10.1016/S0378-4266(99)00110-7

Duan, J. Ch., \& Van Laere, E. (2012). A public good approach to credit ratings - From concept to reality. Journal of Banking \& Finance, 36(12), 3239-3247. http://dx.doi.org/10.1016/j.jbankfin.2012.03.012

Durbarry, R., Seetanah, B., \& Padachi, K. (2008). An Empirical Assessment of External Debt on Economic growth. International Finance and Economics. Available at: http://www.britannica.com/bps/additionalcontent/18/35618410/ an -empirical-assessement-of-external-debt-on-economic-growth-the-case-of-africa-in-a-panel-var.

Eggertsson, G. B., \& Krugman, P. (2012). Debt, Deleveraging, and the Liquidity Trap: A Fisher-Minsky-Koo Approack. Quarterly Journal of Economics, 127(3), 1469-1513. http://dx.doi.org/10.1093/qje/qjs023

Faraglia, E., Marcet, A., \& Oikonomou, R. (2013). The Impact of Debt Levels and Debt Maturity on Inflation. Economic Journal, 123(566), F164-F192. http://dx.doi.org/10.1111/ecoj.12015

Fisher, W. H. (2008). Imports, status preference, and foreign borrowing. Review of Development Economics, 12(1), 1-20.

Fuentes, M., \& Saravia, D. (2010). Sovereign defaulters: Do international capital markets punish them? Journal of Development Economics, 91(2), 336-347. http://dx.doi.org/10.1016/j.jdeveco.2009.06.005

Gatzert, N., \& Martin, M. (2012). Quantifying credit and market risk under Solvency II: Standard approach versus internal model. Insurance Mathematics \& Economics, 51(3), 649-666. http://dx.doi.org/10.1016/j.insmatheco.2012.09.002

Genberg, H., \& Sulatarova, A. (2008). Macroeconomic volatility, debt dynamics, and sovereign interest rate spreads. Journal or International Money and Finance, 27(1), 26-39. http://dx.doi.org/10.1016/j.jimonfin.2007.09.010

Ghosh, A. R., Gulde, A. M., \& Wolf, H. C. (2000). Currency Boards: More Than a Quick Fix? Economic Policy, 15(31), October 2000. Available at SSRN: http://ssrn.com/abstract=247412

Gurtner, F. J. (2003). Currency Boards and Debt Traps: Evidence from Argentina and Relevance for Estonia. World Economy, 26(2), 209-228. http://dx.doi.org/10.1111/1467-9701.00518

Hartwick, J. M. (2011). Green National Income and Green National Product. Annual Review of resource Economics, vol. 3, p. 21-35. http://dx.doi.org/10.1146/annurev-resource-083110-120032

Izak, V. (2009). Primary Balance, Public Debt And Fiscal Variables In Postsocialist Members Of The European Union. Available at http://ideas.repec.org/a/prg/jnlpep/v2009y2009i2id345p114-130.html.

Jeanne, O., \& Ranciere, R. (2011). The optimal level of international reserves for emerging market countries: a new formula and some applications. Economic Journal, 121(555), 905-930. http://dx.doi.org/10.1111/j.14680297.2011.02435.x

Katsimi, M. (2007). Exchange rate strategies towards the euro-zone for new EU member states with currency boards. Journal of Macroeconomics, 30(3), 1043-1063. http://dx.doi.org/10.1016/j.jmacro.2007.04.005

Knedlik, T., \& Von Schweinitz, G. (2012). Macroeconomic Imbalances as Indicators for Debt Crises in Europe. JCMSJournal of common market studies, 50(5), 726-745. http://dx.doi.org/10.1111/j.1468-5965.2012.02264.x

Korinek, A. (2011). Foreign currency debt, risk premia and macroeconomic volatility. European Economic Review, 55(3), 371-385. http://dx.doi.org/10.1016/j.euroecorev.2010.12.008

Legrenzi, G., \& Milas, C. (2012). Nonlinearities and the sustainability of the government's intertemporal budget constraint. Economic Inquiry, 50(4), 988-999. http://dx.doi.org/10.1111/j.1465-7295.2011.00402.x

Liliko, A., Holmse, E., \& Sameen, H. (2009). Controlling Spending and Government Deficits: Lessons from History and International Experience. Policy Exchange, November.

Melecky, M. (2012). Choosing the currency structure of foreign-currency debt: a review of policy approaches. Journal of International Development, 24(2), 133-151. http://dx.doi.org/10.1002/jid.1711

Melecky, M. (2012). Formulation of public debt management strategies: An empirical study of possible drivers. Economic systems, 36(2), 218-234. http://dx.doi.org/10.1016/j.ecosys.2011.08.001

Moinescu, B.-G. (2013). The lending channel and budget balance: empirical evidences from Central and Eastern European economies. Theoretical and Applied Economics, 3(580), 17-30.

Molanescu, G., \& Aceleanu, M. I. (2011). Consequences of the Budget Deficit in the Current Crisis in Romania. Implications on the Labor Market. Theoretical and Applied Economics, 02(555), 59-74.

Neck, R., \& Sturm, J. E. (2009). Sustainability of public debt. Journal of Economics, 97(1), 95-96. http://dx.doi.org/ 10.1007/s00712-009-0060-4

Pattilo, C., Poirson, H., \& Ricci, L. (2004). What are the Channels through which External Debt Affects Growth. IMF Working Paper No. 04/15. Available at http://www.imf.org/external/pubs/ft/wp/2004/wp0415.pdf. 
Aura Draksaite, Vytautas Snieska, Gitana Valodkiene. Prerequisites for Sustainable Government Borrowing Within ...

Pisani, M. (2011). Financial Openess and Macroeconomic Instability in Emerging Market Economies. Open Economies Review, 22(3), 501-532. http://dx.doi.org/10.1007/s11079-009-9140-x

Public sector debt statistics: guide for compilers and users (2011). International Monetary Fund, 2011. Retrieved from http://www.tffs.org/pdf/method/PSDS11fultext.pdf

Snieska, V., \& Draksaite, A. (2010). Contemporary pattern of risk management of debt under economic restructure. Business and Management 2010: the 6th international scientific conference, May 13-14, 2010, Vilnius, Lithuania : selected papers / International North German Academy of Informatology, Stralsund, p. 199-206.

Snieska, V., \& Draksaite, A. (2011). Enhancement of competitiveness of small open economy by upgrading the management of its net foreign debt. Economics and Management - 2011: 16th international conference "Economics and Management", April, 27-29th 2011: program and reviewed abstract book. ISBN 9788021442795 p. $110-111$.

Snieska, V., \& Draksaite, A. (2013). Evaluation of Sustainability of the General Government Debt in a Small Open Economy. Mediterranean Journal of Social Sciences, 4(9), 610-618. http://dx.doi.org/10.5901/mjss. 2013.v4n9p610

Sopek, P. (2009). The effect of the financial crisis on Croatia's primary budget deficit and public debt. Financial Theory and Practice, 33(3), 273-298.

Taylor, L., Proano, Ch. R., de Carvalho, L., \& Barbosa, N. (2012). Fiscal deficits, economic growth and government debt in the USA. Cambridge Journal, 36(1), 189-204. http://dx.doi.org/10.1093/cje/ber041

Thornton, D. L. (2012). The U.S. Deficit/Debt Problem: A Longer-Run Perspective. Federal Reserve Bank of St. Louis Review, 94(6), p. 441-455.

Togay, S., Kose, N. (2013). Money-price relationships under a currency board system: the case of Argentina. Journal of Applied Economics, 16(2), 373-389. http://dx.doi.org/10.1016/S1514-0326(13)60016-1

Tomz, M., \& Wright, M. L. J. (2007). Do countries default in "bad times"? Journal of the European Economic association, 5(2/3), 352-360. http://dx.doi.org/10.1162/jeea.2007.5.2-3.352

Tsang, S. K., \& Ma, Y. (2002). Currency substitution and speculative attacks on a currency board system. Journal of International Money and Finance, 21(1), 53-78. http://dx.doi.org/10.1016/S0261-5606(01)00015-8

Uctum, M., \& Wickens, M. (2000). Debt and Deficit Ceilings, and Sustainability of Fiscal Policy: an Intertemporal Analysis. Oxford Bulletin of Economics and Statistics, no. 62, p. 197-222. http://dx.doi.org/10.1111/14680084.00168

Vaughn, K., \& Wagner, R. (1992). Public debt controversies - an essay in reconciliation. Kyklos, 45(1), p. 37-49. http://dx.doi.org/10.1111/j.1467-6435.1992.tb02106.x

Vlasenko, O., \& Kozlov, S. (2009). Choosing the Risk Curve Type. Technological and Economic Development of Economy, 15(2), 341-351. http://dx.doi.org/10.3846/1392-8619.2009.15.341-351

Von Wijnbergen, S., \& France, A. (2012). Assessing Debt Sustainability in a Stochastic Environment: 200 Years of Dutch debt and Deficit management. Economist-Nederlands, 160(3), 219-236. http://dx.doi.org/10.1007/s10645-012-9188-7

The article has been reviewed.

Received in December 2015; accepted in April, 2016. 